\title{
Present status of distribution, utilization and commercialization of Zanthoxylum armatum DC. - a socio economically potential species in Arunachal Pradesh, India
}

\author{
Padma Raj Gajurel ${ }^{*}$, Soyala Kashung, Sisibaying Nopi \& Binay Singh \\ Department of Forestry, North Eastern Regional Institute of Science and Technology, Nirjuli 791109, Arunachal Pradesh, India \\ *Email: prgajurel@gmail.com
}

\section{ARTICLE HISTORY}

Received: 12 October 2020

Accepted: 08 January 2021

Published: 09 February 2021

\section{KEYWORDS}

Zanthoxylum armatum

Distribution

Population

Economic and traditional use

Harvesting

Marketing

\section{ABSTRACT}

The utilization of wild plants for livelihood and income generation is a traditional practice adopted by various indigenous communities worldwide. Zanthoxylum armatum DC. is one of the most preferred species harvested from wild and used extensively by the local indigenous communities in the northeastern part of India as well as in the neighbouring countries like Bhutan and Nepal. This species has been widely used by the local tribes as a spice in flavouring various foodstuffs and also for the treatment of numerous health ailments. We studied the distribution, population, ethnobotanical uses and marketing potentials of Zanthoxylum armatum in 12 districts of Arunachal Pradesh during 20182019. The study revealed its occurrence in the subtropical and temperate forest of the state with maximum population in forest edges and open forests around agricultural lands of West Kameng and Lower Subansiri districts. The analysis of the population in Shergaon area revealed its good representation with $1.04 / \mathrm{m}^{2}$ density contributing $0.051 \mathrm{~m}^{2} / \mathrm{ha}$. basal cover and $20.011 \mathrm{IVI}$. Even after its various uses, no cultivation of the species was practised by the local people. The dried fruits that are marketed @Rs. 800-1200/kg in the state are entirely collected from the wild. As the population of the species is limited in most of the area and the supply of fruits is only from the wild, extensive plantation and management practices will serve both the conservation as well the economic gain to the local communities.

\section{Introduction}

Arunachal Pradesh, one of the 8 northeastern states, situated in the Indian Eastern Himalaya is bestowed with rich bio and floristic diversity. Around 5000 flowering plants have so far been reported to occur in different habitats of the state and most of them are economically and medicinally valuable (1). The state is equally rich in cultural and ethnic diversity where 26 major tribal communities with numerous subgroups reside having rich indigenous knowledge system on diversified resources. The use of wild plants for livelihood and socio-economic development is a common practice in the state. They utilize diversified plant species for colouring, flavouring, seasoning and preservation in the preparation of various local cuisines (2-3). Species of bamboos, cane, medicinal plants, wild edible plants etc. growing in the state having good commercial demand are extensively used by the local communities. Zanthoxylum armatum DC. belongs to the family Rutaceae is one such species with high economic importance (4). The tree is muchbranched, deciduous and spinous growing up to $6 \mathrm{~m}$ height in its natural habitats (Fig. 1) and is characterized by its highly pungent and aromatic fruits and leaves. The species which is commonly known as 'Winged prickly ash', or 'Timur', or 'Toothache tree', is widely used as a spice in household kitchens and is widely sold in the local markets either raw or in dried forms $(5,6)$. The species apart from being widely used as spices and condiments also has high medicinal values. All plant parts such as leaves, fruits, stem, bark and seeds are used in the preparation of various indigenous medicines for treating ailments like common cough, bronchitis, toothache, fever, stomach disorders etc. (7-9).

(c) Gajurel et al (2021). This is an open-access article distributed under the terms of the Creative Commons Attribution License, which permits unrestricted use, distribution and reproduction in any medium, provided the original author and source are credited (https://creativecommons.org/licenses/by/4.0/)

To cite this article: Gajurel P R, Kashung S, Nopi S, Singh B. Present status of distribution, utilization and commercialization of Zanthoxylum armatum DC. - a socio economically potential species in Arunachal Pradesh, India. Plant Science Today. 2021;8(1):210-217. https://doi.org/10.14719/pst.2021.8.1.993 

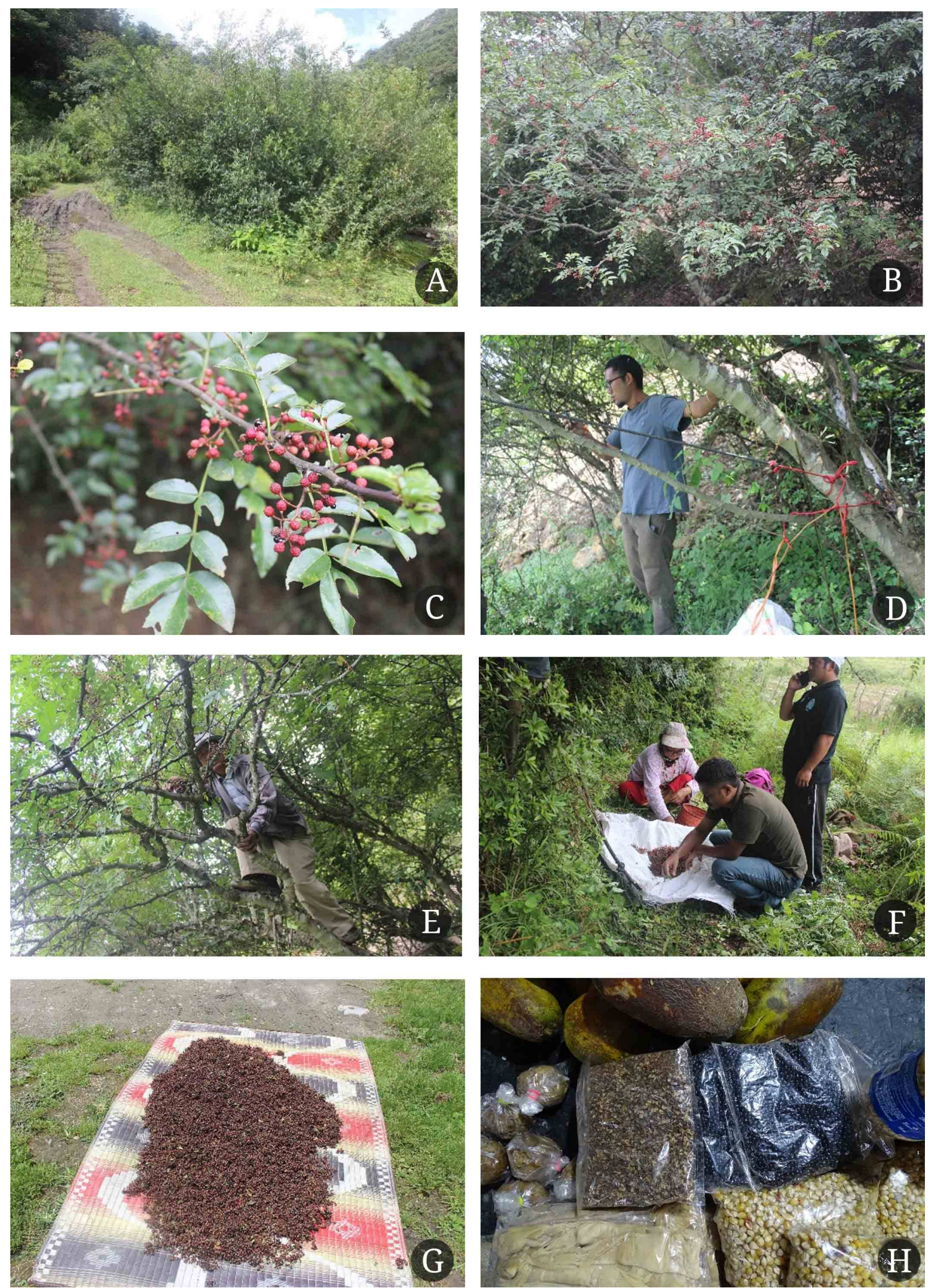

Fig. 1. Zanthoxylum armatum A. Plants in natural habitat B \& C. Fruiting in the wild D \& E. Harvesting of fruits F. Cleaning of fruits G. Drying of the fruits $\mathbf{H}$. Fruits and seeds sold in the local market.

Progressive studies carried out by various researchers regarding the presence of various chemical compounds and biological activities resulted in the isolation of several metabolites such as essential oils, alkaloids, flavonoids, coumarins amides, lignins etc. (10-12) and various biological activities such as antioxidative, antinociceptive, antiinflammatory $(10,13)$, antimicrobial, antihelmintic
(14), hepato-protective (15), piscicide (16) etc. Due to suitable pharmacological characteristics, it was always acclaimed internationally with its escalating prices during the last two decades (17).

The species is widely distributed throughout China, Japan, Laos, Malaysia, Nepal, Philippines, Pakistan, South-North Korea, Taiwan, Vietnam etc. at 
an altitudinal range of 1000-1500 m (18). In India and adjacent countries, it is located in the hotter valleys of subtropical to temperate Himalayas from Kashmir to Arunachal Pradesh including Bhutan and Nepal, Odisha and Andhra Pradesh in the Eastern Ghats, and in the Khasi Hills, Naga Hills, Mizo Hills and Manipur in the northeast region within the altitudinal range of 700 - $2500 \mathrm{~m}$ (7). Open pastures, wastelands, secondary scrub forests, degraded slopes, natural forests and wastelands with adequate rainfall, with clay or loamy soil are considered as suitable habitats for the species (19).

Despite its economic and ethnobotanical values, the species is still collected from the wild without any judicious practices. To improve the yield and economic return, there is a need for proper management of the species with suitable eco-climatic conditions in the region. Hence, to initiate and support the management practices, a field study has been conducted to understand the present status of distribution, population and utilization pattern with the existing commercial value. The information already available for the species has also been incorporated in the results.

\section{Materials and Methods}

To understand the present distributional pattern and utilization, field surveys were conducted in different selected areas of Arunachal Pradesh $\left(26^{\circ} 01^{\prime} 00^{\prime \prime} \mathrm{N}\right.$ and 94028'43”E) during 2018-2019. For the field survey, 12 districts were targeted including the districts where the occurrence of Zanthoxylum armatum has been reported. Field surveys were conducted in some selected localities of the districts to find out the distribution, population, ethnobotanical uses and economical status. The distribution pattern and status of occurrence in each of the surveyed areas have also been observed through forest walks involving local communities. For trading of the species, the local markets of the said districts as well as the Itanagar capital complex were surveyed. The detailed ethnobotanical uses, their harvesting practices etc. have been collected through discussion and personal interaction with the local communities (20).

To find out its population status in the best suitable habitat of the state, an ecological study through quadrat method was being conducted in the Shergaon area of West Kameng district. The study area is located at an altitudinal zone of $1900-2100$ msl and lies in between $27^{\circ} 7^{\prime}$ to $27^{\circ} 15^{\prime} \mathrm{N}$ and $92^{\circ} 15^{\prime}$ to $92^{\circ} 30^{\prime} \mathrm{E}$. Quadrats of $10 \times 10 \mathrm{~m}$ size were laid randomly in selected areas having the population of the species and all trees and shrubs within each quadrat were recorded. Altogether, 25 quadrats were sampled. Important community parameters such as the density of distribution, frequency, abundance and Importance Value Index (IVI) of the species along with the associated ones were computed following standard procedure $(21,22)$. The IVI values for all species were computed by summing up the relative values of frequency and density. The species diversity index $\left(\mathrm{H}^{\prime}\right)$ was determined using the method given by Shannon and Wiener (23).

$$
H^{\prime}=-\sum_{i=1}^{S} p i \ln p i
$$

Where, $\mathrm{H}^{\prime}$ = Shannon - Wiener diversity index, $p i$ is the proportion of individuals in the $\mathrm{i}^{\text {th }}$ species i.e. $\left(n_{i} /\right.$ $N)$; $n_{i}=$ importance value index of the species; and $\mathrm{N}=$ importance value index of all the species. The dominance index was calculated using Simpson's index (24).

$$
D=\sum_{i=1}^{S}(p i)^{2}
$$

Where, $\mathrm{D}$ is the Simpson's dominance index and $p i$ is the same as for the Shannon - Wiener diversity.

\section{Results and Discussion}

\section{Distribution}

The present field survey and investigation showed the well existence of the species in the eastern Himalayan state of Arunachal Pradesh. Out of the 12 districts covered in the study, the species was recorded from 8 ones. Among the surveyed areas the plant could not be located in Changlang, Namsai, Lohit and Lower Dibang valley. The distributional features revealed that the status of occurrence in the 8 districts was quite variable and in majority of the areas the species was found with very rare and scarce population. The major areas where the population of the species was recorded are presented in Table 1 and Fig. 2. The study indicated that the species although is found to occur within a diverse elevation range starting from $200 \mathrm{~m}$ up to $2600 \mathrm{~m}$, the population is more common in the higher elevational range particularly beyond $1000 \mathrm{~m}$. It has also been reported that among the various areas surveyed, the species was best represented by a good and sizeable population only in 3 districts namely Lower Subansiri, Papum Pare and West Kameng in the localities namely i.e. Yachuli, Yazali, Sagalee, Shergaon and Bomdila in the elevation range of 1000 to $2200 \mathrm{~m}$. The populations in all the localities were found usually with very sparse distribution having only a few individuals in most of the areas. However, in forests of Shergaon, the population was better represented with 5-6 individuals in clumps. The observations on the distributional and population pattern in a selected forest in Shergaon revealed that, they were growing mostly in forest margins, open areas near agriculture fields and roadsides in association with various trees and shrubs. The species like Alnus nepalensis, Pyrus pashia, Quercus serrata, Eurya acuminata, Castanopsis indica, Zanthoxylum acanthopodium, Gaultheria fragrantissima, Elaeagnus parviflora, Lyonia ovalifolia, Rhododendron arboretum etc. were found well associated with the species. The individuals of the species were not found under the dense canopy of the forests indicating the preference of light for their better adaptation and growth. A study on the population status through sampling in one of the major distributional area i.e. Shergaon under West Kameng district resulted the occurrence of 26 individuals of $Z$. armatum, which depicted the 
Table 1. Distribution pattern of Z. armatum in Arunachal Pradesh

\begin{tabular}{|c|c|c|c|c|}
\hline Sl. no. & District & Localities & Altitudinal range (m) & Status of Occurrence* \\
\hline \multirow{2}{*}{1.} & \multirow{2}{*}{ Anjaw } & Musai & $1200-1400$ & Rare \\
\hline & & Kundan & $1200-1350$ & Nil \\
\hline 2. & Pakke-Kesang & Seijosa & $200-350$ & Rare \\
\hline \multirow{4}{*}{3.} & \multirow{4}{*}{ Lower Subansiri } & Ziro & $1500-1600$ & Fairly good \\
\hline & & Joram & $1650-1750$ & Fairly good \\
\hline & & Yachuli & $1350-1600$ & Good \\
\hline & & Yazali & $1250-1500$ & Good \\
\hline \multirow{3}{*}{4.} & \multirow{3}{*}{ Papum Pare } & Sagalee & $850-1000$ & Good \\
\hline & & Toru & $600-700$ & Rare \\
\hline & & Mengio & $1200-1400$ & Fairly good \\
\hline \multirow{2}{*}{5.} & \multirow{2}{*}{ Dibang Valley } & Anini & $1600-1700$ & Rare \\
\hline & & Mipi & $1400-1500$ & Rare \\
\hline \multirow{3}{*}{6.} & \multirow{3}{*}{ Upper Siang } & Yingkiong & $450-600$ & Rare \\
\hline & & Komkar & $520-700$ & Rare \\
\hline & & Tuting & $500-900$ & Rare \\
\hline \multirow{3}{*}{7.} & \multirow{3}{*}{ West Kameng } & Shergaon & $1900-2100$ & Good \\
\hline & & Bomdila & $2000-2600$ & Good \\
\hline & & Rupa & $1400-1800$ & Fairly good \\
\hline \multirow{3}{*}{8.} & \multirow{3}{*}{ Tirap } & Khonsa & $650-1100$ & Rare \\
\hline & & Thinsa & $1400-1600$ & Rare \\
\hline & & Soha & $200-300$ & Rare \\
\hline
\end{tabular}

(*based on the field observation made in the surveyed locality. Nil- population not seen; Rare- less than 5 individual mature trees; Fairly good: up to 20 mature trees; Good- more than 20 mature individuals).

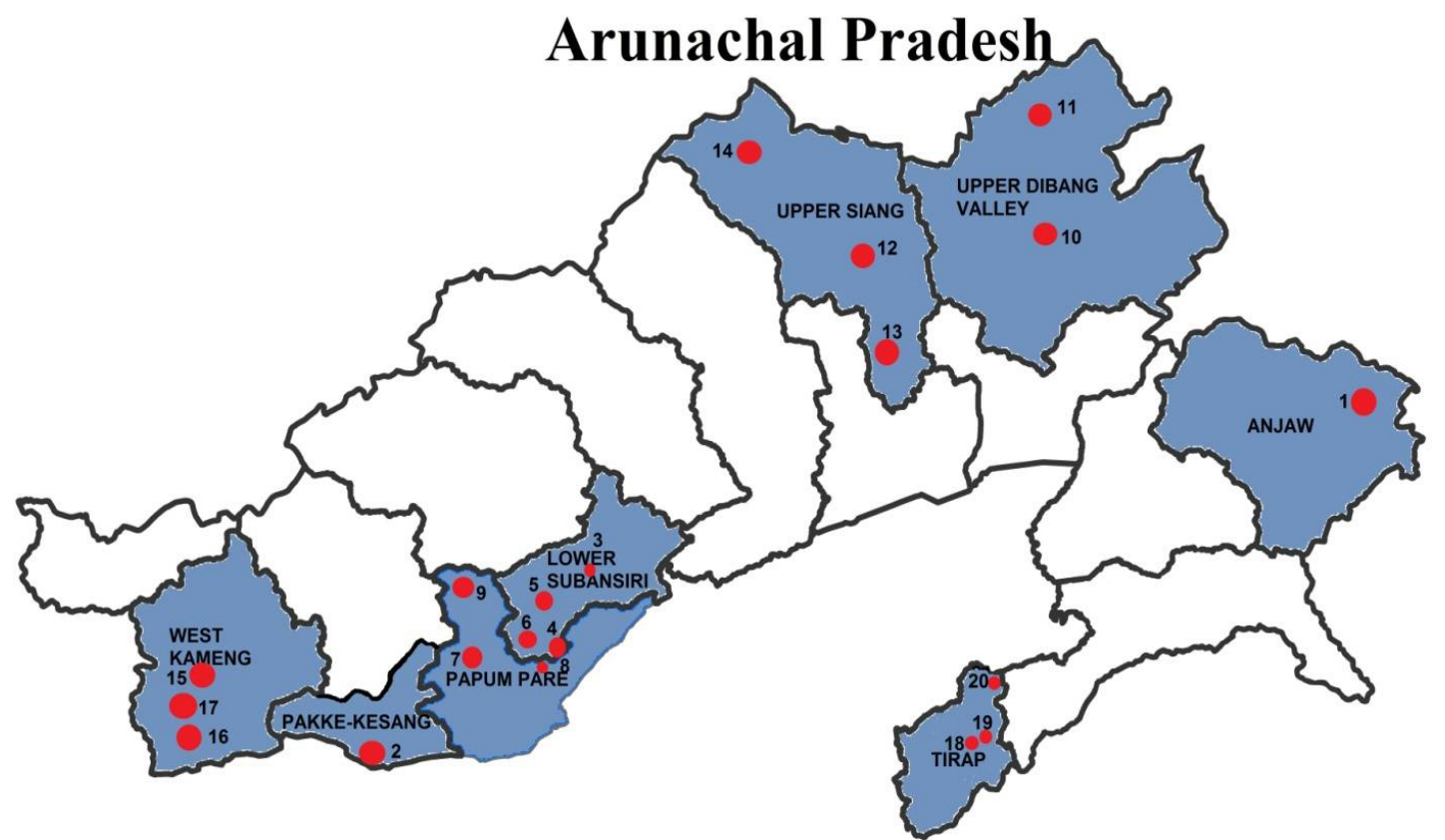

Fig. 2. Map of Arunachal Pradesh showing the distribution of Z. Armatum.

1. Musai 2. Seijosa 3. Ziro 4. Joram 5. Yachuli 6. Yazali 7. Sagalee 8. Toru 9. Mengio 10. Anini 11. Mipi

12. Yingkiong 13. Komkar 14. Tuting 15. Bomdila 16. Shergaon 17. Rupa 18. Khonsa 19. Thinsa 20. Soha

density of the species as $104 \mathrm{ha}^{-1}$ contributing 0.051 $\mathrm{m}^{2} /$ ha. basal cover. The computed Shannon-Wiener index of the species was found 0.230 while the Simpson index showed comparatively a low value (0.010). The results of the population sampling indicated a good population status in the selected sites. Another species of Zanthoxylum i.e. Z. acanthopodium also indicated a better population with a density of $80 \mathrm{ha}^{-1}$. A total of 40 tree species under 29 genera spread over 19 families were recorded in the community with varied density. The recorded population pattern of some important tree species occurring in the habitat of $Z$. armatum is presented in Table 2.

\section{Utilization pattern}

\section{Uses of the species}

The species is already well known for its different economic and ethnobotanical values, which is to commonly use as spices and condiments by the people of northeast. Other Asian countries like Bhutan, China, Japan, Malaysia, Nepal and Pakistan 
also use it in the form of spices, condiments and for other therapies. The detailed uses of the species from India and other Asian countries are presented in Table 3.

In the present investigation, attempts have been taken to record the detailed uses of the species by different ethnic communities. It has been found that almost all the tribes of the state use the species mostly as a spice. However, the tribes also consider the species as an ethnomedicinal plant and use to cure fever, cold, cough etc. The plant is locally called as Ombae (Adi), Yorkhung (Apatani), Brum sing (Memba), Yer/Zabrang (Monpa), Hanam/Honyum (Nyishi), Suiji (Sartang), Tsogok (Tangsa) etc. Besides the fruits, the leaves and bark is also being used by the tribes. According to the survey, fruit is the prime commercial part while the other two parts i.e. the leaves and barks are consumed locally at the household or community level, but not yet commercialized. The fruits are used both in raw and dried form and the raw ones are used in the preparation of chutney, while the dried fruits are used as spice and condiments. The young tender shoots and leaves are cooked as vegetables as well as in preparing chutney for its aromatic smell. Fresh leaves are also used for stupefying fishes for an easy catch. The twigs are also found to be used as a toothbrush by some of the tribes. The plant is also found to serve as an excellent live fence in agricultural fields and household borders due to its thick and strong thorns.

Most of the local tribes of the state, especially those inhabiting the interior areas are still dependent on the traditional healthcare system due to the inaccessibility owing to rough terrain of the state and poor road condition. This species was largely used in the treatment of various ailments like cold, fever, indigestion and other stomach disorders which was commonly found among the tribal communities of the state. Consumption of the dried fruit as spice or in chutney for alleviating sleep by the Nyishi tribe was unique (Table 4). Some of the uses reported in botanical survey have also been worked out by some researchers of the state $(31,32,34,37)$.

\section{Harvesting and Management practices}

The cultivation of the species is not commonly practised by the tribes. The locals are collecting the species mostly from the wild habitats. However, sometimes the young seedlings growing in the forests are collected and raised in the agricultural fields, home gardens, or as a live fence. Fruit collection takes place during August-September when the fruits ripened and are collected manually either by looping the branches or climbing the trees or sometimes placing cloth or tarpaulin under the tree (Fig. 1). No other specific techniques were found adopted for the fruit collection. Sometimes the branches are also cut down for easier picking. Before selling the fruits are dried properly and the undesired parts and other materials were removed through hand picking. The seeds segregated during the drying and processing are separated before marketing.

During the survey it was found that the fruits were harvested for commercial purposes in the selected areas, but without any plantation management. However, in the areas namely Shergaon and Bomdila in West Kameng district, the local communities used to manage the species in its natural habitats allowing the newly regenerated seedlings for adaptation and removing the old and less productive plants. As the species is not commonly cultivated and the collection is done mainly from the wild, restrictions need to be enforced during the processing period to curb over harvesting and destruction of the plant. However, as the plants yield huge amount of fruits, a good number of fruits are left over either in the tree or ground after harvesting leaving some seeds available for natural regeneration. Moreover, the seeds are discarded in commercial packaging as only the follicle is used. In rare cases only, the communities cut down the plants for harvesting. So the process of traditional harvesting does not pose big threats to the plants.

The limited population of the species in most of the area and the continuous destruction of natural habitats warrants for large scale cultivation and management. No cultivation and management practices have been initiated in the state either by the communities or other Govt. departments including the forest department of the state. Raising seedlings from the seeds in the nursery and their plantation in the suitable habitats may lead for scaling up the commercial cultivation.

\section{Marketing status}

The field survey and study conducted in different parts of the state revealed that the fruits of $Z$. armatum are commercialized by the local communities, mostly harvesting from the forests. The materials collected from different forest areas are either sold in the local markets or supplied to the markets of the capital complex. The survey of the different markets selling the wild forest products in the capital complex like Banderdewa, Chimpu, Doimukh, Ganga, Naharlagun and Nirjuli indicated that almost $90 \%$ of $Z$. armatum sold in the markets of the capital complex comes from three distinct localities Yazali, Shergaon and Sagalee. However, as per the local vendors, the samples collected from Shergaon areas have higher demand and preference among the mass. The freshly plucked fruits were sold at Rs. $30-40$ per packet (approx. $50 \mathrm{gm}$ ) while the dried fruits were sold at Rs. 600-800 per kg. during peak period and Rs. 900-1200 per kg. during the off season in the local markets. The present market prices of the dried fruits in other states of northeast particularly in Assam, Manipur, Nagaland and Meghalaya are also found comparatively higher with an average rate of Rs. $700-800 \mathrm{~kg}$. As per the information from the villagers of the surveyed sites, the crop is helping the locals to generate good revenues during its harvesting seasons. The locals collect around 1 to $4 \mathrm{~kg}$. of fruits per tree which in turn help them to earn approximately Rs. 500 to Rs. 2000 after drying.

It is found that among the various forest resources sold in the markets, the fruits of $Z$. armatum can be rated as one of the highly demanded 
Table 2. Population status of $Z$. armatum with some commonly associated tree species in Shergaon area of Arunachal Pradesh

\begin{tabular}{|c|c|c|c|c|c|}
\hline Species & Frequency \% & $\begin{array}{c}\text { Density } \\
\text { (Individual ha-1 }^{-1} \text { ) }\end{array}$ & IVI & $\begin{array}{c}\text { Shannon-Weiner } \\
\text { index }\end{array}$ & $\begin{array}{c}\text { Simpson } \\
\text { index }\end{array}$ \\
\hline Acer pectinatum Wall. ex G.Nicholson & 16 & 28 & 6.7967 & 0.1150 & 0.0012 \\
\hline Alnus nepalensis D.Don & 32 & 48 & 12.5240 & 0.1735 & 0.0039 \\
\hline Aralia sp. & 16 & 24 & 6.2619 & 0.1085 & 0.0010 \\
\hline Betula utilis D.Don & 16 & 24 & 6.2619 & 0.1085 & 0.0010 \\
\hline Castanopsis indica (Roxb. ex Lindl.) A.DC. & 12 & 12 & 3.8943 & 0.0767 & 0.0004 \\
\hline Elaeagnus parvifolia Wall. ex Royle & 12 & 12 & 3.8943 & 0.0767 & 0.0004 \\
\hline Eurya acuminata DC. & 48 & 72 & 18.7860 & 0.2221 & 0.0088 \\
\hline Gaultheria fragrantissima & 16 & 20 & 5.7272 & 0.1017 & 0.0008 \\
\hline Juglans sp. & 16 & 16 & 5.1924 & 0.0948 & 0.0007 \\
\hline Litsea sp. & 12 & 16 & 4.4291 & 0.0844 & 0.0005 \\
\hline Lyonia ovalifolia (Wall.) Drude & 24 & 36 & 9.3929 & 0.1436 & 0.0022 \\
\hline Pinus wallichiana A.B.Jacks. & 12 & 16 & 4.4291 & 0.0844 & 0.0005 \\
\hline Populus ciliata Wall. ex Royle & 12 & 16 & 3.6657 & 0.0733 & 0.0003 \\
\hline Pyracantha crenulata (Roxb. ex D.Don) M.Roem. & 12 & 20 & 4.9638 & 0.0917 & 0.0006 \\
\hline Pyrus pashia Buch.-Ham. ex D.Don & 20 & 20 & 6.4905 & 0.1112 & 0.0011 \\
\hline Quercus lamellosa Sm. & 16 & 20 & 5.7272 & 0.1017 & 0.0008 \\
\hline Quercus serrata Murray & 24 & 28 & 8.3235 & 0.1323 & 0.0017 \\
\hline Rhododendron arboreum Sm. & 12 & 20 & 4.9638 & 0.0917 & 0.0006 \\
\hline Salix tetrasperma Roxb. & 12 & 16 & 4.4291 & 0.0844 & 0.0005 \\
\hline Wendlandia coriacea (Wall.) DC. & 20 & 20 & 6.4905 & 0.1112 & 0.0011 \\
\hline Zanthoxylum acanthopodium DC. & 28 & 80 & 16.0387 & 0.2024 & 0.0064 \\
\hline Zanthoxylum armatum DC. & 32 & 104 & 20.0106 & 0.2303 & 0.0100 \\
\hline
\end{tabular}

Table 3. The reported uses of different parts of Z. armatum

\begin{tabular}{clll}
\hline Sl. no. & Part used & Uses & Selected references \\
1. & Fruit & $\begin{array}{l}\text { Consumed raw or cooked as vegetable, in chutney preparation, as spice and condiments } \\
\text { Treatment against abdominal pain, rheumatism, skin disease, flatulence, cough and cold, } \\
\text { tonsillitis, headache, fever, vertigo, diarrhea, dysentery, indigestion, cholera, ear } \\
\text { infection }\end{array}$ & $(6,25-37)$ \\
\hline 2. & Seeds & $\begin{array}{l}\text { Treatment against cold, cough, fever, indigestion, flatulence, depression, increase } \\
\text { appetite }\end{array}$ & $(34,37,38)$ \\
\hline 3. & Leaves & Young tender leaves are cooked as vegetable & $(6,33,36,39)$ \\
\hline 4. & Twigs & As toothbrush for toothache and gum problems & $(30,36)$ \\
\hline 5. & Bark & Treatment against cholera, diabetes, asthma & $(28)$ \\
\hline
\end{tabular}

Table 4. Ethnobotanical uses of Z. armatum by different tribes of Arunachal Pradesh

\begin{tabular}{clll}
\hline Sl. no. & Name of Tribe & Local name & Ethnobotanical use \\
\hline 1. & Adi & Ombae & Young leaves cooked as vegetable; fruits for cough and cold; seeds for improving appetite \\
\hline 2. & Apatani & Yorkhung/Yarkhung & $\begin{array}{l}\text { Fruit and dried seed powder consumed for treating cold, cough, fever; twigs as } \\
\text { toothbrush }\end{array}$ \\
\hline 3. & Idu mishmi & Athasimbo & Fruit consumed as spice, against fever, common cold, improving digestion \\
\hline 4. & Memba & Brum sing & Leaves as vegetable; twigs as toothbrush; fruits for cough \\
\hline 5. & Monpa & Yer/Zabrang/Khagi & $\begin{array}{l}\text { Dried fruit as spice and condiments, treatment against cold and cough, bronchitis, throat } \\
\text { pain }\end{array}$ \\
\hline 6. & Nyishi & Hanam/Honyum & $\begin{array}{l}\text { Raw fruit as chutney, dried fruit as spice and condiment, treatment against cold and } \\
\text { cough, improving digestion, throat problem, alleviating sleep }\end{array}$ \\
\hline 7. & Nocte & Chiaruh & Leaves as vegetables; dried fruits for improving digestion, cold and cough, fever \\
\hline 8. & Tangsa & Changkao/ Tsogok & Fruits and bark for stupefying fishes, for improving digestion, cold and cough \\
\hline
\end{tabular}

forest products having the potentiality of generating regular income for both the villagers and the vendors. If we assume to get $4 \mathrm{~kg}$. of fruits from a single tree, the farmer can earn an income of about Rs. 3200. So, by managing 20 individuals of the species in an area, a farmer can earn an income of about Rs. 64000 from a single harvest season.

Although the data on the present marketing rate of the species from other parts of the country and abroad is scanty, the earlier data revealed that in the local markets of Uttarakhand, the species was sold at Rs. 45 per kg. in the hills, while in the plains the price was raised from Rs. 150 to 200 per $\mathrm{kg}$. during 2005 (7). In Nepal, during 2007, the fruits were reported to be sold at Rs. 90-120 per kg (Nepali Rupees) and
Zanthoxylum oil at Rs. $3500-4000$ per $\mathrm{kg}$ (40). Commercially the dried fruits are known mostly as Timur or Sichuan pepper and are traded in various parts of the country. Presently in India, the dried fruits are sold as commercial spice under different brand names at a price range of Rs. 1500 to 5000 per kg. As per the Indian e-commerce company, IndiaMART, the seeds are being sold at Rs. 300013000 per kg depending on the sellers in the Indian market (41). The following are some of the brand names of the Timur fruits sold in the market.

1. Myor Pahad's Exotic Super Food Timur Seeds (Sichuan Pepper) 70 GMS Stand-Up Zipper Pouch 100\% Naturally Sourced from Uttarakhand 100 gm. @Rs. 500/ 100 gm (42). 
2. Pahari Roots Indian Sichuan Peppercorn (90\% unseeded) from The Hills of Meghalaya 100 gm (2 Packs of 50 gm each) @ Rs. 250 (43).

3. Leeve Dry Fruits Strong Natural Aroma Sichuan Pepper 200 gm. @ Rs. 300 (44).

Some other commercialized industrial products which use timur as an essential ingredient include Zuroor-e-Qula, Dabur Toothpaste, Dabur Lal Dantmanjan, MDH Dantmanjan, ZenthoDent, Zanthoxylum organic Nepal, Tomar seed oil etc. (7, 45-48). Besides various pharmacological industries, timur is also used in insect repellents and vermicide materials.

Looking at the local, regional and national commercial demand and availability of the population in the state of Arunachal Pradesh, $Z$. armatum could become one of the best choices for the local communities as livelihood generation and venture for socio-economic development.

\section{Conclusion}

Zanthoxylum armatum DC. is ear marked as one of the important forest crop having significant ethnobotanical values. The species is having a high market demand and price with potential for revenue generation. Besides the well-known uses of the species as toothpaste, the fruits of the species are now known to be used in commercial spices to increase flavor. It is one of the most locally preferred and commercially demanded wild forest species in the northeastern region of the country. With the increasing demand in the national and international markets and with its rising price every year one can safely promote the cultivation and marketing of this species in the state. Due to its extensive local uses and growing market demand without proper management and harvesting protocols, there is an expected threat to the wild population of the species. The proper harvesting and processing of the fruits in the villages may help in improving the quality of the marketed fruits, thereby ensuring more market price. The abundant jhum land and other marginal forest lands available in the region can be used for commercial cultivation and management of the species. The Biodiversity Management Committees (BMCs) established as per the Biodiversity Act., 2002 of the country should be involved in regulation of the harvesting and marketing of the species for larger benefits to the local communities.

\section{Acknowledgements}

We thank the villagers and the local vendors of the study area for sharing their valuable knowledge on the traditional use and marketing of the species, and their support during the survey and study. The authors are thankful to the Department of Biotechnology, Govt. of India, for the financial support [No. BT/01/17/NE/TAX]. The authors are also grateful to the Director, NERIST, and Head, Department of Forestry for providing all necessary facilities.

\section{Authors' contributions}

PRG and BS designed the objectives and plan of work. SK and SN carried out the field work, analyzed the data and wrote the manuscript. PRG and BS helped in data analysis, interpretation and manuscript correction.

\section{Conflict of interests}

The authors declare no conflict of interest.

\section{References}

1. Singh P, Dash SS. Plant discoveries 2015. India: Botanical Survey of India; 2016. https://www.researchgate.net/publication/305144491_Plant_Dis coveries_2015

2. Singh RK, Pandey KB, Syed IR. Medicinal properties of some Indian spices. Annals of Phytomedicine. 2012;1(1):29-33. http:// www.ukaazpublications.com/publications/wp-content/uploads /2019/01/C-4-Medicinal-Properties.pdf

3. Srinivasan K. Role of spices beyond food flavoring: Nutraceuticals with multiple health effects. Food Reviews International. 2005;21(2):167-88. https://doi.org/10.1081/FRI200051872

4. Singh M, Shikha D. Zanthoxylum armatum DC: past, present and future prospective. International Journal of Biological Sciences. 2017;7(1):21-24. http://indianjournals.com/ijor.aspx? target=ijor:bto\&volume $=7$ \&issue $=1$ \&article $=002$

5. Phuyal N, Jha PK, Raturi PP, Rajbhandary S. Zanthoxylum armatum DC.: Current knowledge, gaps and opportunities in Nepal. Journal of Ethnopharmacology. 2018;229:326-41. https:/ doi.org/10.1016/j.jep.2018.08.010

6. Bharali P, Singh B, Sharma CL. Ethnobotanical survey of spices and condiments used by some tribes of Arunachal Pradesh. Journal of Medicinal Plants Studies. 2017;5(1):101-09. https://dx.doi.org/10.7439/ijasr.v3i1.3843

7. Kala CP, Farooquee NA, Dhar U. Traditional Uses and Conservation of Timur (Zanthoxylum armatum DC.) through Social Institutions in Uttaranchal Himalaya, India. Conservation and Society. 2005;3(1)224-30.

8. Manandhar NP. Plants and People of Nepal. USA: Timber Press, Inc.; 2002.

9. Singh OJ, Raleng I, Premchand M, Debashree N. A review on the pharmacological profiles of Zanthoxylum armatum DC (Rutaceae). Journal of Evolution of Research in Medical Pharmacology. 2016;2(1):10-12.

10. Sati SC, Sati MD, Raturi,R, Badoni P. Anti-inflammatory and antioxidant activities of Zanthoxylum armatum stem bark Global Journal of Researches in Engineering. 2011;11(5):21-23.

11. Waheed A, Mahmud S, Akhtar M, Nazir T. Studies on the components of essential oil of Zanthoxylum armatum by GCMS. American Journal of Analytical Chemistry. 2011;2(2):25861. https://doi.org/10.4236/ajac.2011.22031

12. Paul A, Kumar A, Singh G, Choudhary A. Medicinal, pharmaceutical and pharmacological properties of Zanthoxylum armatum: A Review. Journal of Pharmacognosy and Phytochemistry. 2018;7(4):892-900.

13. Guo T, Deng YX, Xie H, Yao CY, Cai CC, Pan SL, Wang YL. Antinociceptive and anti-inflammatory activities of ethyl acetate fraction from Zanthoxylum armatum in mice. Fitoterapia. https://doi.org/10.1016/j.fitote.2010.11.004

14. Mehta MB, Kharya MD, Shrivastva R, Verma KC. Antimicrobial and antihelmintic activities of the essential oil of Zanthoxylum alatum Roxb. Indian perfumer. 1981;25:19-21. 
15. Ranawat LS, Bhatt J, Patel J. Hepatoprotective activity of ethanolic extract of bark of Zanthoxylum armatum DC. in CC14 induced hepatic damage in rats. Journal of Ethnopharmacology. 2010;127(3):777-80. https://doi.org/10.1016/j.jep.2009.10.019

16. Ramanujam SN, Ratha BK. Effect of alcohol extract of a natural piscicide - Fruits of Zanthoxylum armatum DC. on Mg2+ and $\mathrm{Na}^{+}, \mathrm{K}+$-ATPase activity in various tissues of a freshwater airbreathing fish, Heteropneustes fossilis. Aquaculture. 2008;283 (1-4):77-82. https://doi.org/10.1016/j.aquaculture.2008.07.033

17. Hertog $\mathrm{W}$, Wiersum K. Timur (Zanthoxylum armatum) production in Nepal. Mountain Research and Development. 2000;20(2):136-45. $\quad$ https://doi.org/10.1659/02764741(2000)020[0136:TZAPIN]2.0.CO;2

18. Nair KN, Nayar MP, editors. Flora of India (MalpighiceaeDicapetalaceae). Vol. 4. India: Botanical Survey of India; 1997.

19. Kunwar RM, Pokharel YR. Zanthoxylum armatum DC. (Timur, Toothache tree) seeds in changing climate. Abstract: Proceedings of the $6^{\text {th }}$ National Conference on Science and Technology; 2012; NAST, Kathmandu, Nepal.

20. Jain SK, Goel AK, editors. A Manual of Ethnobotany. India: Scientific Publishers, Jodhpur; 1995.

21. Misra R. Ecology Work Book. India: Oxford and IBH Publishing Company, New Delhi; 1968.

22. Mueller-Dombois D, Ellenberg H. Aims and Methods of Vegetation Ecology. USA: John Wiley and Sons, New York; 1974.

23. Shannon CE, Wiener $\mathrm{W}$. The mathematical theory of communities. USA: University of Illinois Press, Urbana; 1963.

24. Simpson EM. Measurements of diversity. Nature. 1949;163(4148): 688.

25. Watson E. The Principal Articles of Chinese Commerce. China: Statistical Department of the Inspectorate General of Customs; 1930.

26. Rajbhandari KR. Ethnobotany of Nepal. Nepal: Ethnobotanical Society of Nepal; 2001.

27. Angami A, Gajural PR, Rethy P, Singh B, Kalita SK. Status and potential of wild edible plants of Arunachal Pradesh. Indian Journal of Traditional Knowledge. 2010;5(4):541-50.

28. Baral SR, Kurmi PP. A compendium of medicinal plants in Nepal. Nepal: Rachana Sharma Publication; 2006.

29. Geweli MB, Awale S. Aspects of Traditional Medicine in Nepal. Japan: Institute of Natural Medicine University of Toyama; 2008.

30. Abbasi AM, Khan MA, Ahmed M, Zafar M. Herbal medicines used to cure various ailments by the inhabitants of Abbottabad district, North West Frontier Province, Pakistan. Indian Journal of Traditional Knowledge. 2010;9:175-83.

31. Srivastava RC, Nyishi Community. Traditional knowledge of Nyishi (Daffla) tribe of Arunachal Pradesh. Indian Journal of Traditional Knowledge. 2010;9(1):26-37.

32. Khongsai M, Saikia SP, Kayang H. Ethnomedicinal plants used by different tribes of Arunachal Pradesh. Indian Journal of Traditional Knowledge. 2011;10(3):541-46.

33. Murtem G, Chaudhry P. An ethnobotanical note on wild edible plants of Upper Eastern Himalaya, India. Brazilian Journal of Biological Sciences. 2016;3(5):63-81. https://doi.org/10.21472/bjbs.030506

34. Ayam VS. Ethnomedicine of Wild Plants of Ziro, Arunachal Pradesh. International Journal of Research Studies in
Biosciences. 2017;5(7):1-12. https://doi.org/10.20431/23490365.0507001

35. Tsering J, Gogoi BJ, Hui PK, Tam N, Tag H. Ethnobotanical appraisal on wild edible plants used by the Monpa community of Arunachal Pradesh. Indian Journal of Traditional Knowledge. 2017;16 (4):626-37.

36. Momang T, Dipankar B, Rinyo R, Tag $\mathrm{H}$. Wild food plant resources of Komkar Adi tribe of Upper Siang district in Arunachal Pradesh, India. Bulletin of Arunachal Forest Research. 2018;33(2):27-35.

37. Das SK, Das TJ, Tshering D, Tsering J, Paul D, Gupta DD, et al. Ethnobotanical notes on significant food and medicinal flora used by the indigenous Monpa and Nyishi communities of Arunachal Pradesh, India. Pleione. 2019;13(2):291-304 https://doi.org/10.26679/Pleione.13.2.2019.291-304

38. Zaidi SFH, Yamada K, Kadowaki M, Usmanghani K, Sugiyama T. Bactericidal activity of medicinal plants, employed for the treatment of gastrointestinal ailments, against Helicobacter pylori. Journal of Ethnopharmacology. 2009;121(2):286-91. https://doi.org/10.1016/j.jep.2008.11.001

39. Lungphi $\mathrm{P}$, Wangpan $\mathrm{T}$, Tangjang $\mathrm{S}$. Wild edible plants and their additional uses by the Tangsa community living in the Changlang district of Arunachal Pradesh, India. Pleione. 2018; 12(2):151-64. https://doi.org/10.26679/Pleione.12.2.2018.151-164

40. Nepal WWF. Gift of the Himalayas: Non-Timber Forest Products of the Sacred Himalayan Landscape - Nepal [Internet]. Nepal: WWF; 2007 [cited 2020 September 20]. Available from: https://www.wwfnepal.org/?118460/gift-of-thehimalayas-high-value-plants-and-ntfps

41. Anonymous. Timur [Internet]. IndiaMART [cited 2020 October 05]. Available from: https://indiamart.com/proddetail/timur19460632755.html

42. Anonymous. Myor Pahad's Exotic Super Food Timur Seeds [Internet]. Amazon India [cited 2020 October 05]. Available from: https://amazon.in/Myor-Sichuan-Stand-Up-NaturallyUttarakhand/dp/B085PRY3W3/ref=sr_1_1?

dchild $=1 \&$ keywords $=$ myor + pahad $\% 27 \mathrm{~s}+$ timur\&qid $=1602214735 \& s r=8-1$

43. Anonymous. Pahari roots Indian Sichuan Peppercorn [Internet]. Amazon India [cited 2020 October 05]. Available from: https://amazon.in/Pahari-Roots-Peppercorn-unseededMeghalaya/dp/B08B6CY67R/ref=sr 1 1? dchild=1\&keywords=Pahari+Roots+Indian+Sichuan+Peppercor n\&qid $=1602469842 \& s r=8-1$

44. Anonymous. Leeve Dry Fruits Strong Natural Aroma Sichuan Pepper [Internet]. Amazon India [cited 2020 October 05] Available from: https://amazon.in/Leeve-Dry-Fruits-NaturalSichuan/dp/B01N2A6TRO/ref=sr_12? dchild=1\&keywords=Leeve+Dry+Fruits+Strong+Natural+Arom $\mathrm{a}+$ Sichuan+Pepper\&qid=1602469689\&sr $=8-2$

45. Paridhavi M, Agrawal SS. Safety evaluation of a polyherbal formulation, Zuroor-e-Qula. Natural Product Radiance. 2007; 6(4):286-89.

46. CSIR-National Botanical Research Institute. ZenthoDent [Internet]. India; 2019 [cited 2020 October 05]. Available from: https://nbri.res.in/achievements/products-technologies

47. Anonymous. Zanthoxylum organic Nepal [Internet]. Zayat Aroma [cited on 2020 October 05]. Available from: https://www.zayataroma.com/en/oils/zanthoxylum

48. Anonymous. $100 \%$ Pure \& Natural Tomar Seed Oil (Zanthoxylum armatum) [Internet]. Alibaba Company [cited 2020 October 05]. Available from: https://alibaba.com/productdetail/100-Pure-Natural-Tomar-Seed-Oil_50038256624.html? $\mathrm{spm}=$ a2700.galleryofferlist.normal_offer.d_title.5b204144YyUUdw 